\title{
AID and the law
}

\author{
D J Cusine Department of Private Law, University of Glasgow
}

The present state of the law is unsatisfactory. The exact effect on the marriage of the parties has not been decided although in English law if artificial insemination by donor (AID) takes place without consent that would appear to be a ground for divorce since 1969. The law regards a child born as a result of AID as illegitimate and draws no distinction between the case where the husband consents and where he does not. Theoretically, an offence is committed if the birth entry is falsified, presumably in cases where the husband consents. The AID child, like any other illegitimate child, has rights against the natural parents, but he is in a worse position than most illegitimate children, in that he may not have any information about his father.

It is now possible to freeze sperm and so preserve it over longer periods. All the problems associated with AID are present also when sperm is preserved in banks, but if the law is in an unsatisfactory state in relation to $A I D$ this is even more true in relation to sperm banks. The main criticism of the Feversham Report (1960) could be that it recommended, broadly speaking, the 'status quo' but scientific progress has now overtaken and left the Feversham findings well behind. What, therefore, is required is a full consideration of the subject of AID and, on the basis of that, some statutory code regulating all its aspects.

The legal aspects of artificial insemination by donor (AID) can be considered from two main standpoints: I) What is the effect on the marriage of the recipient and her husband; and 2) what is the status of the resultant child?

\section{The effect of AID on a marriage}

On the first of these points, the only direct authority in the United Kingdom is the Scottish case of MacLennan v. MacLennan (1958) where it was held that AID without the husband's consent did not amount to adultery. Adultery is sexual intercourse between two parties either or both of whom is married but not married to the other, and for sexual intercourse to take place there must be some degree of penetration of the female organ by the male organ. It therefore followed, in Lord Wheatley's opinion, that AID, even without consent, did not constitute adultery, and he referred to both Scots and English authority including Dennis v Dennis (1955). There is an observation by Lord Dunedin in Russell v Russell (I924) to the effect that fecundation $a b$ extra is adultery, but his view was irrelevant to the decision and furthermore was not supported by authority. For these reasons, it has not been followed in the line of authority referred to in the case of MacLennan.

There is one previous Commonwealth case (I92I) where the question of AID was ventilated. The judge's opinion was not strictly relevant to the case, but he did favour the view that AID without the consent of the husband was adultery. His reasoning is doubtful. Adultery in his opinion is the 'voluntary surrender to another person of the reproductive powers and faculties of the guilty person: and any submission of these powers to the service or enjoyment of any person other than the husband or the wife comes within the definition of "adultery" '. It would follow from this that anyone who could not surrender the reproductive powers to another could not be guilty of adultery. No one who is sterile could therefore commit adultery. It is also doubtful whether the acceptance of AID is a submission 'to the service or enjoyment of' the donor. In a case involving the status of a child born as a result of AID (1956) the judge also expressed an obiter opinion that AID was adultery.

So far as Scotland is concerned, Lord Wheatley recognized that if done without consent AID was offensive to the marital bond, but rightly pointed out that to make it a new ground of divorce would require legislation. Both the Royal Commission on Marriage and Divorce (1956) and the Feversham Committee (1960) were of the view that the practice should be made into a ground of divorce which it probably now is if it amounts to conduct which would justify the husband in refusing to continue to live with his wife in terms of the Divorce Reform Act 1969 (sec. 2(I)(b)). This Act does not extend to Scotland where divorce law reform still awaits Parliamentary time. It is at least arguable that if AID is obtained by a wife without the husband's consent, that would amount to cruelty in Scots law. The test is first to find out what was actually done and secondly to ascertain what effect it had on the physical or mental health of the other party. There are few decisions in Scotland where the only cruelty alleged has involved the sexual activities of the parties, but in a recent case (1966) an act of 
gross indecency by the husband was held to have struck at the root of the matrimonial relationship and it was proved that the conduct affected the wife's health. Artificial insemination by donor without consent, it is submitted, strikes more forcibly at the root, and, if it affected the husband's health, the court would possibly find that the wife had been guilty of cruelty.

Where AID takes place with the husband's consent, he would be barred from founding on this in any divorce action in which he sought to use that AID as the ground. In Scots law, it would be regarded as either connivance or condonation or both. Since 1969 connivance is no longer a defence in England to an action of divorce (Divorce Reform Act, section 3) and so the court would probably view the husband's conduct as a condonation.

Whether or not the husband has consented, the artificial insemination of the wife, whether or not by the husband's seed, does not amount to consummation of the marriage ( $\mathrm{L} \mathrm{v} \mathrm{L,} \mathrm{1949);} \mathrm{but} \mathrm{while} \mathrm{in}$ England wilful refusal to consummate a marriage is a ground of nullity of marriage that is not the case in Scotland. The question is always one of the capacity of the spouses for sexual intercourse.

\section{The status of a child born of AID}

What is possibly more important is the status of the resultant child. The case of MacLennan (1958) did not consider the question of status, but the Feversham Committee were in no doubt that a child born as a result of AID, whether or not the husband consented, is illegitimate. It could be argued from the case of MacLennan (1949) that, since AID without the husband's consent is not adultery, then the child is prima facie legitimate. It is submitted that this is incorrect. There is a presumption in law - pater est quem nuptiae demonstrant - that the husband of the wife is the father of her child. This is a rebuttable presumption and can be so rebutted by proof of adultery, but this is only one way of showing that the child was conceived as a result of the introduction of sperm other than that of the husband. It follows that proof of AID rebuts the presumption. That is the legal position: the medical position is the same and the law would be unrealistic if it dissented from the medical view in a matter like this. That being the case, no distinction need or can be drawn between AID to which the husband consented and that to which he did not. It is alien seed and so the child is illegitimate.

It is submitted, however, that in practice there is a distinction between the husband/child relationship in the two cases. If the husband consented, although in law the child's status is clear, de facto the father may register the child as his own (thus incidentally committing an offence) or more importantly it will be brought up as one of the family. If this is so, it will be alimented and educated in the same way as a legitimate child would have been and the husband $\frac{\pi}{\mathbb{O}}$

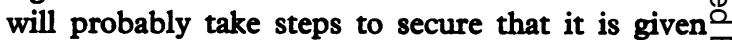
succession rights in his estate. It is unlikely, though $\underset{F}{F}$ not impossible, that the court will require to consider that child's position as an AID child which? is accepted as one of the family. The Matrimonial $\overrightarrow{\bar{F}}$ Proceedings (Children) Act 1958 gives the courto power to deal with the custody, maintenance, and $\frac{}{\circ}$ education of a child which has been accepted as one $\overline{\bar{c}}$ of the family, and before decree is granted in an $\widehat{\nabla}$ action of divorce, nullity, or separation, the Court must be satisfied that satisfactory arrangements ${ }^{\text {s }}$ have been made for the child's upbringing. The $\overrightarrow{0}$ Feversham Committee suggested in paragraph $159 \overrightarrow{-}$ that a child born as a result of AID to which the ${ }^{\omega}$ husband consents should be given by statute the same rights to aliment as an adopted child which $\widetilde{\Phi}$ in turn are the same as those of a legitimate child.(Adoption Act 1958). The writer doubts whether $\vec{\omega}$ rights of aliment and rights of succession can be or should be treated differently. If they were so 5 considered, the child would be treated in exactly the $\overrightarrow{-}$ same way as a legitimate child until the husband died, and then he could be excluded from succession to his estate. The position in relation to succession $\vec{\theta}$ in the wife's estate is slightly different in that the U) illegitimate child has an equal right with legitimate children to the estate of an intestate (1968, 1969).

If the same rights of aliment and succession were granted to the child, as are presently available to adopted children, that would confer on the child the $\frac{}{8}$ same status as the adopted child. That situation $\vec{\Rightarrow}$ would differ completely from other acquisitions of status, the conferring of which is done by some legally recognized process, eg, the adoption petition. An Act of Parliament might confer the status, but it would only do so if it could be proved that the $\overline{\widehat{\Phi}}$ AID was done with consent and the proof to that $:-$ consent would still be required. This might be 3 . difficult, particularly after the husband's death, and $\delta$ so it is suggested that this is not the correct approach. 3 The only solution which is satisfactory is to have a new status of 'accepted' child, but even that is not free from difficulty.

However, where the child is born as a result of AID to which the husband has not consented, it is ज less likely that he would accept the child and he $N$ might refuse to aliment it. Indeed the husband $N$ might leave the marital home, or in England seek a $O$ divorce, the result of which could be that the child could be in a difficult financial position with only his

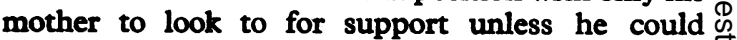
ascertain the identity of the donor, assuming that he even knows the circumstances of his birth. Certainly if the child could establish the identity $\overrightarrow{\mathbb{D}}$ of the donor, he would be entitled to support from $\frac{?}{\mathbb{D}}$ him as his illegitimate child. The writer under- $\varrho$ stands that before semen is given the donor signs a document to the effect that the seed is given on 8 condition that his name is not revealed. That 
condition governs only the donor/practitioner relationship and the practitioner/recipient relationship, but does not affect the child, but the writer is of the opinion that there is no legal process in Scotland or England whereby the child could ascertain the name of the donor. The existence of a special statutory remedy for the adopted child would seem to bear this out (Adoption Act 1958). However, the child's status might have to be proved in succession claims and rights of aliment on divorce. Does it follow that the donor's identity would be revealed? In the case of MacLennan (1958), Lord Wheatley criticized the lack of specification in the wife's pleadings. 'Having admitted the long period of non access, the birth of a child, all that the defender states by way of pleading is that the child was conceived as a result of artificial insemination by a donor. Such a bald assertion offends against all the canons of specification and fair notice and it was recognized by her counsel that, unless much fuller specification was given in relation to the time, place and circumstances of the alleged artificial impregnation of the defender, the attack on the relevancy of the defence would have to be sustained... Obviously in his view the wife would have had to put more detail into her pleadings and thereafter lead evidence. In the end of the day she decided not to, but had she done so it seems inevitable that the name of the practitioner would be revealed. This would raise questions of secrecy and the Hippocratic Oath. It is not therefore possible to say that the discharge signed by the donor is an effective bar to all future inquiry. Indeed, Lord Wheatley gave some guidance on what additional material the wife would have had to put in her pleadings when he spoke of 'much fuller specification ... in relation to the time, place and circum- stances of the alleged impregnation.... He did not go so far as to say that he would require the donor's name to be revealed, but neither did he explain what he meant by the word 'circumstances'. This area of difficulty and others only arise if the AID child is regarded as illegitimate. This view was also taken in Illinois in Doornbos v. Doornbos and presumably would be taken also in Italy (Battaglini, 196I), where it is a criminal offence. However, some states in the United States regard an AID child, whose conception was consented to by the husband in writing, as a legitimate child.

\section{References}

Adoption Act 1958, sections 13, 22(4).

Battaglini, G (196I). Artificial insemination and adultery in a recent Italian trial. Crim. $L$ R, 765.

Dennis v Dennis 1955. p 153.

Divorce Reform Act 1969, section 3.

Doornbos v Doornbos 1956. I39 NE 21844.

Family Law Reform Act 1969, section 134 .

L v L 1949. p 2 r.

Law Reform (Miscellaneous Provisions) (Scotland) Act 1968, sections I-3.

MacLennan v MacLennan, I958 SC 105.

Matrimonial Proceedings (Children) Act 1958.

Orford v Orford I92I 49 OLR I5.

Report of the Departmental Commission on Human Artificial Insemination (Feversham), $1960 \mathrm{Cmnd}$. II05.

Royal Commission on Marriage and Divorce (1956). Cmnd. 9678.

Russell v Russell 1924 AC 687 at 721 .

White $\mathrm{v}$ White 1966. SC 187. 